\title{
Contribution of scintigraphy and ultrasonography to the prediction of malignancy in thyroid nodules with indeterminate cytology
}

\author{
Contribuição da cintilografia e ultrassonografia para a predição de \\ malignidade em nódulos tireoidianos com citologia indeterminada
}

Pedro Weslley Rosário',2, Daniela Santos Salles', Breno Bessa', Saulo Purisch²

'Programa de Pós-graduação, Santa Casa de Belo Horizonte, Belo Horizonte, MG, Brasil ${ }^{2}$ Departamento de Tireoide, Serviço de Endocrinologia, Santa Casa de Belo Horizonte, Belo Horizonte, MG, Brasil

\section{Correspondence to: Pedro Weslley Rosário Av. Francisco Sales, 1.111, 9 D - Santa Efigênia 30150-221 - Belo Horizonte, MG Brasil pedrorosario@globo.com}

Received on May/30/2009 Accepted on Oct/16/2009

\begin{abstract}
Objective:To evaluate the contribution of ${ }^{131}$ scintigraphy and ultrasonography to the prediction of malignancy in thyroid nodules with indeterminate cytology in euthyroid patients. Subjects and methods: The sample consisted of 102 patients with thyroid nodules, submitted to FNAC and presenting an indeterminate cytological diagnosis (follicular neoplasm). Results: Malignancy was observed in 19/25 (76\%) nodules with suspicious ultrasonographic characteristics versus $5 / 77(6.5 \%)$ without suspicious findings. When ${ }^{131}$ s scintigraphy showed a cold or hot nodule, the chance of malignancy was $38.5 \%$ and $2.5 \%$, respectively. This exam was inconclusive in $10 \%$ of the patients. Conclusions: Surgery is indicated when a thyroid nodule with indeterminate cytology exhibits suspicious ultrasonographic characteristics. Otherwise, ${ }^{131}$ scintigraphy can exclude thyroidectomy when reveals uptake in the nodule, which is observed in half the cases. Arq Bras Endocrinol Metab. 2010;54(1):56-9
\end{abstract}

Keywords

Thyroid nodule; indeterminate cytology; radionuclide imaging; ultrasonography

\section{RESUMO}

Objetivo: Avaliar a contribuição da cintilografia com ${ }^{131} \mid$ e da ultrassonografia na predição de malignidade em nódulos tireoidianos com citologia indeterminada em pacientes eutireoidianos. Sujeitos e Métodos: A amostra foi composta por 102 pacientes com nódulos tireoidianos submetidos à punção aspirativa com agulha fina (PAAF), apresentando citologia indeterminada (neoplasia folicular). Resultados: Malignidade foi encontrada em 19/25 (76\%) nódulos suspeitos na ultrassonografia versus 5/77 (6,5\%) naqueles sem características suspeitas. Quando a cintilografia com ${ }^{131}$ I mostrou nódulo hipo- ou hipercaptante, a chance de malignidade foi $38,5 \%$ e $2,5 \%$, respectivamente, e em $10 \%$ dos pacientes esse exame foi inconclusivo. Conclusões: Cirurgia está indicada quando um nódulo tireoidiano com citologia indeterminada exibe características ultrassonográficas suspeitas. Quando não as exibe, a cintilografia com ${ }^{131}$ I pode dispensar a tireoidectomia se revelar captação correspondente ao nódulo, o que ocorre em metade dos casos. Arq Bras Endocrinol Metab. 2010;54(1):56-9

Descritores

Nódulo tireoidiano; citologia indeterminada; cintilografia; ultrassonografia

\section{INTRODUCTION}

A though fine needle aspiration cytology (FNAC) is the best method for the definition of the nature of thyroid nodules, in about $20 \%-25 \%$ of the cases, cytology is indeterminate, i.e., it suggests "follicular neoplasm". Some investigators recommend surgery for all patients with this result, but the fact that approximately $80 \%$ of the patients have benign disease justifies the effort to better select candidates for thyroidectomy. Scintigraphy is traditionally recommended, with a hot nodule being defined as benign (1). Molecular markers are promising but have not yet been sufficiently validated for use in cli- 
nical practice (2). Ultrasonographic findings have shown to be good predictors of malignancy in these lesions (3-5).

Within this context, we evaluated the contribution of ${ }^{131}$ I scintigraphy and ultrasonography to the prediction of malignancy in thyroid nodules with indeterminate cytology in euthyroid patients.

\section{SUBJECTS AND METHODS}

All patients examined by the first author (P.W.S.R.) between 2003 and 2008 who had thyroid nodule(s) were eligible for this study. Nodules $\leq 1 \mathrm{~cm}$ without suspicious ultrasonographic characteristics and hot nodules detected by ${ }^{131}$ I scintigraphy performed on patients with low TSH were not submitted to FNAC. The present sample consisted of nodules submitted to FNAC presenting an indeterminate cytological diagnosis (follicular neoplasm). Patients exposed to neck radiation during childhood and adolescence, patients with a family history of medullar or papillary carcinoma (in the latter case, at least two first-degree relatives), patients with nodule-related symptoms, or nodules $\geq 4 \mathrm{~cm}$ were managed differently and were excluded from the study. Six of 108 patients with a contraindication to surgery or who refused to submit to surgery were also excluded. The sample consisted of 102 patients ( 80 women, age range: $12-85$ years, mean: 50 years) with nodules ranging in size from 1.2 to $3.9 \mathrm{~cm}$. Only histological diagnosis of the thyroid nodule with indeterminate cytology was considered for analysis. The study was approved by the Research Ethics Committee [Santa Casa de Belo Horizonte (Protocol number 027/2006)].

Ultrasonography was performed with a linear multifrequency $10-12 \mathrm{MHz}$ transducer for morphological analysis and with a 4.5-7 MHz transducer for color-Doppler evaluation. The images were analyzed by experienced professionals. Suspicious ultrasonographic characteristics were microcalcifications; marked hypoechogenicity (when a nodule showed a relatively hypoechoic pattern with regard to the adjacent strap muscle); or two or more findings between hypoechogenicity, microlobulated and irregular margin, predominantly central flow, and taller than wide in shape (being greater in the anteroposterior dimension than in the transverse dimension).

FNAC was performed with a 22 -gauge needle and a 5- or $10-\mathrm{mL}$ syringe. The smears were stained with hematoxylin-eosin and analyzed by pathologists experienced in thyroid pathology.

Fisher's exact test or the $\chi^{2}$ test was used to detect differences in the proportion of cases. A p-value of less than 0.05 was considered significant.

\section{RESULTS}

Histology revealed malignancy in $24(23.5 \%)$ patients, papillary carcinoma in 15 (follicular variant in 12 ), follicular carcinoma in 8 (minimally invasive in 6), and medullar carcinoma in one. Malignancy was observed in $19 / 25(76 \%)$ nodules with suspicious ultrasonographic findings versus $5 / 77(6.5 \%)$ without suspicious characteristics $(\mathrm{p}<0.05)$. When ${ }^{131}$ I scintigraphy showed a cold or hot nodule the chance of malignancy was $38.5 \%$ and $2.5 \%$, respectively $(\mathrm{p}<0.05)$. The presence of malignancy according to the ultrasonographic and scintigraphic results is shown in table 1.

\section{DISCUSSION}

According to the literature, frequency of malignancy in thyroid nodules $<3-4 \mathrm{~cm}$ with indeterminate cytology (follicular neoplasm) ranges from $10-30 \%(3,7)$, in agreement with the present results. A nodule size $>3-4 \mathrm{~cm}$ seems to be associated with a higher chance of malignancy in these cases (7), but this has not been demonstrated in all series $(3,8)$. In the case of nodules $\geq 4 \mathrm{~cm}$, our experience showed a $35 \%$ frequency of malignancy (unpublished data), a rate slightly higher than that observed in the present study for nodules $<4 \mathrm{~cm}$ (24\%). Another important finding was that papillary carcinoma was the most frequent malignancy (62.5\%), with the follicular variant of papillary thyroid carcinoma

Table 1. Frequency of malignancy in thyroid nodules with indeterminate cytology according to ultrasonographic findings and the results of ${ }^{131}$ s scintigraphy

\begin{tabular}{lcccc}
\hline $\begin{array}{l}\text { Method } \\
\text { Ultrasonography }\end{array}$ & \multicolumn{2}{c}{ Scintigraphy } & \multirow{2}{*}{ Total } \\
\cline { 2 - 4 } & Cold nodule & Hot nodule & Inconclusive & $19 / 25(76 \%)$ \\
\hline Suspicious nodule & $16 / 18(89 \%)$ & $1 / 4$ & $2 / 3$ & $5 / 77(6.5 \%)$ \\
Non-suspicious nodule & $4 / 34(11.7 \%)$ & $0 / 36(0 \%)$ & $1 / 7$ & $24 / 102(23.5 \%)$ \\
Total & $20 / 52(38.5 \%)$ & $1 / 40(2.5 \%)$ & $3 / 10$ & \\
\hline
\end{tabular}


corresponding to $80 \%$ of cases. In a recent large series, $85 \%$ of malignant nodules with "follicular neoplasm" cytology were of the papillary type (3), including $85 \%$ of the follicular variant of papillary carcinoma. The classical and limited differential diagnosis between adeno$\mathrm{ma}$ and follicular carcinoma is no longer appropriate for current cases of indeterminate cytology.

Considering the fact that $70 \%-90 \%$ of nodules with indeterminate cytology are benign, proposals to better select candidates for surgery are needed. Factors that increase the risk of thyroid malignancy, such as exposure to neck radiation during childhood, a family history of medullar or papillary thyroid carcinoma and ipsilateral paralysis of the vocal cord, are observed in exceptional cases. With respect to nodule size $>4 \mathrm{~cm}$, in addition to doubts about whether this finding is indeed associated with an increased risk of malignancy $(3,8)$, nowadays it is rarely observed in nodular thyroid disease. Although scintigraphy is not a routine test for the investigation of thyroid nodules, it continues to be recommended for nodules $>1 \mathrm{~cm}$ with indeterminate cytology (1). Uptake in the nodule indicates its benign nature and spares patients from surgery due to the argument of malignancy suspicion. In fact, hot nodules are rarely malignant (9-12) and in the present study only $1 / 40$ hot nodules (with indeterminate cytology) was a carcinoma. ${ }^{131} \mathrm{I}$ or ${ }^{123} \mathrm{I}$ is the preferential tracer since some malignant nodules that appear as cold nodules when using these tracers may be hot nodules upon technetium scintigraphy, probably because they maintain the capacity of uptake but not the organification of iodide (1). However, scintigraphy does not always permit an unequivocal interpretation as observed in $10 \%$ of the studied cases.

Today, almost all patients with thyroid nodules are submitted to ultrasonography and its value for the differentiation between benign and malignant nodules is well established $(6,13,14)$. This fact renders ultrasonography a highly attractive tool for the selection of candidates for surgery in the case of an indeterminate cytological diagnosis. In the present study using characteristics of high specificity $(6,13,14)$, the likelihood of malignancy in nodules $>1 \mathrm{~cm}$ with suspicious ultrasonographic characteristics and indeterminate cytology was $76 \%$ (versus $6.5 \%$ without these findings). The combination of ultrasonographic characteristics and indeterminate cytology was found to be useful for the prediction of malignancy, but there is still no consensus on which characteristics should really be considered $(3,4,5,14,15)$.
The results of the present study allow us to propose a preliminary algorithm for patients presenting thyroid nodules with indeterminate cytology (Figure 1), combining the results of ultrasonography and scintigraphy. The probability of malignancy increases from $23.5 \%$ to $76 \%$ when the nodule exhibits suspicious ultrasonographic characteristics. On the other hand, this probability is nearly zero in the absence of suspicious findings and when scintigraphy shows radioiodine uptake in the nodule.

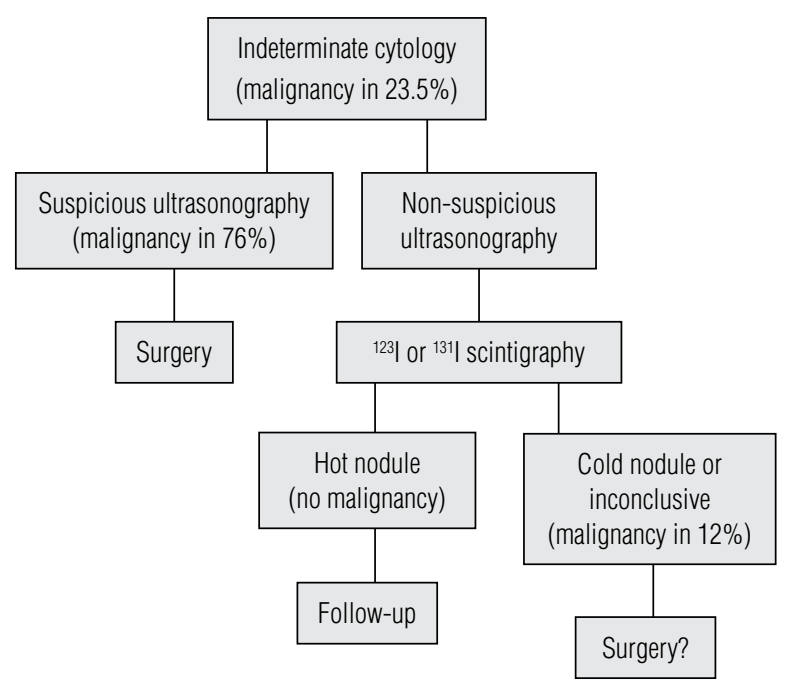

Figure 1. Proposal for the management of patients with thyroid nodules and indeterminate cytology.

One limitation of the present study is the small sample size, and the effectiveness of the proposed management needs to be confirmed in larger multicenter studies. New predictive parameters of malignancy, such as FDG uptake (16) or molecular markers (2), are particularly required for cold nodules without suspicious radiological characteristics since, though surgery was indicated, only $12 \%$ were malignant. Further studies are necessary to determine in which cases these new tests may add information or eventually even replace traditional methods (scintigraphy and ultrasonography) in the investigation of thyroid nodules with indeterminate cytology.

Acknowledgements: this study was not supported by research funds.

Disclosure: no potential conflict of interest relevant to this article was reported.

\section{REFERENCES}

1. Maia AL, Ward LS, Carvalho GA, Graf H, Maciel RM, Maciel LM, et al. Thyroid nodules and differentiated thyroid cancer: Brazilian consensus. Arq Bras Endocrinol Metab. 2007;51(5):867-93. 
2. Cerutti JM. Nodule diagnosed as follicular patterned lesion: are biomarkers the promise? Arq Bras Endocrinol Metab. 2007;51(5):832-42.

3. Rago T, Di Coscio G, Basolo F, Scutari M, Elisei R, Berti P, et al. Combined clinical, thyroid ultrasound and cytological features help to predict thyroid malignancy in follicular and Hürthle cell thyroid lesions: results from a series of 505 consecutive patients. Clin Endocrinol (Oxf). 2007;66:13-20.

4. Gulcelik NE, Gulcelik MA, Kuru B. Risk of malignancy in patients with follicular neoplasm: predictive value of clinical and ultrasonographic features. Arch Otolaryngol Head Neck Surg. 2008;134(12):1312-5.

5. Levine RA. Value of Doppler ultrasonography in management of patients with follicular thyroid biopsy specimens. Endocr Pract. 2006;12(3):270-4.

6. Papini E, Guglielmi R, Bianchini A, Crescenzi A, Taccogna S, Nardi $F$, et al. Risk of malignancy in nonpalpable thyroid nodules: predictive value of ultrasound and color-Doppler features. J Clin Endocrinol Metab. 2002;87(5):1941-6.

7. Stang MT, Carty SE. Recent developments in predicting thyroid malignancy. Curr Opin Oncol. 2009;21(1):11-7.

8. RaberW, Kaserer K, Niederle B, Vierhapper H. Risk factors for malignancy of thyroid nodules initially identified as follicular neoplasia by fine-needle aspiration: results of a prospective study of one hundred twenty patients. Thyroid. 2000;10(8):709-12.
9. Rieger R, Pimpl W, Money S, Rettenbacher L, Galvan G. Hyperthyroidism and concurrent thyroid malignancies. Surgery. 1989;106(1):6-10.

10. Mann K. Evaluation of risk in autonomously functioning thyroid nodules. Exp Clin Endocrinol Diabetes. 1998;106(Suppl 4):S23-6.

11. Chao TC, Lin JD, Jeng LB, Chen MF. Thyroid cancer with concurrent hyperthyroidism. Arch Surg. 1999;134(2):130-4.

12. Ahuja S, Ernst H. Hyperthyroidism and thyroid carcinoma. Acta Endocrinol (Copenh). 1991;124:146-51.

13. Frates MC, Benson CB, Charboneau JW, Cibas ES, Clark OH, Coleman BG, et al. Management of thyroid nodules detected at US: Society of Radiologists in Ultrasound consensus conference statement. Radiology. 2005;237(3):794-800.

14. Tomimori EK, Bisi H, Medeiros-Neto G, Camargo RY. Ultrasonographic evaluation of thyroid nodules: comparison with cytologic and histologic diagnosis. Arq Bras Endocrinol Metab. 2004;48(1):105-13.

15. Kwak JY, Kim EK, Kim HJ, Kim MJ, Son EJ, Moon HJ. How to combine ultrasound and cytological information in decision making about thyroid nodules. Eur Radiol. 2009;19(8):1923-31.

16. Sebastianes FM, Cerci JJ, Soares Júnior J, Zanoni PH, Tomimori EK, de Camargo RY, et al. Preoperative evaluation of cytologically indeterminate thyroid nodules with 18F-FDG PET. Arq Bras Endocrinol Metab. 2008;52(7):1176-83. 